\title{
Model Penilaian Bahasa Indonesia Dalam Pelaksanaan Kurikulum Sekolah Dasar
}

\author{
Ambari Sutardi \\ Pusat Kurikulum, Balitbang, Kemendiknas
}

\begin{abstract}
Abstrak: Model penilaian Bahasa Indonesia dalam pelaksanaan kurikulum SD berbeda dari sebelumnya, di mana perbedaan tersebut dimaksudkan agar para pelaksana memahami dalam menerapkan model penilaian di beberapa SD di kabupaten/kota yang berbeda. Perbedaan menggunakan model mulai dari yang sederhana hingga ke yang kompleks. Sederhana artinya hanya mencantumkan satu nilai untuk mata pelajaran tersebut dan kompleks karena mencantumkan empat nilai, untuk empat kategori kompetensi dalam berbahasa Indonesia, yaitu: mendengarkan, berbicara, membaca dan menulis. Penggunaan aneka ragam model penilaian Bahasa Indonesia akan menimbulkan permasalahan karena sistem penilaian memiliki pengaruh kuat terhadap pelaksanaan pembelajaran di kelas. Dikhawatirkan keempat kategori kompetensi Bahasa Indonesia yang telah ditetapkan tidak akan tercapai secara optimal oleh peserta didik, terutama sekolah yang menggunakan model penilaian yang sederhana. Oleh karena itu, model penilaian Bahasa Indonesia yang ideal merupakan model yang kompleks, dengan harapan agar penyampaian informasi tentang prestasi dapat dicapai peserta didik secara rinci dan objektif.
\end{abstract}

Kata kunci: multi teknik, model penilaian ideal.

\begin{abstract}
The evaluation model for Indonesian language sustaining the implementation of the in-effect primary school curriculum is different from the previous one. Accordingly, this results in different perceptions and different use of the model by the implementers at some primary schools in different districts/ municipalities. The difference of using the model are ranging from the simple to the more complext. The simple one merely covers one score for the subject concerned while the complext one encompasses four scores, for: listening, speaking, reading and writing respectively. The use of various evaluation models for Indonesian language would certainly results in a problem because the evaluation system has strong impact againsts the learning process in the classroom. So it is worried that the four predetermined competence catagories of Indonesian language would not totally be achieved by students in the primary schools which use the simple model one. Because of such reason, the ideal evaluation model to sustain the implementation of the an in-effect primary school curriculum is the complex one so that it would tell the information about learners' achievement in more detailed and transparent.
\end{abstract}

Key words: Multi-techniques, the ideal evaluation model.

\section{Pendahuluan}

Berdasarkan kurikulum 1994 dan kurikulum sebelumnya, model penilaian di sekolah dasar (SD) hanya meliputi satu nilai untuk satu mata pelajaran dan kebijakan ini berlaku secara nasional selama puluhan tahun. Model tersebut tidak dapat menggambarkan prestasi peserta didik yang sesungguhnya. Akibatnya, pihak pembaca rapor (guru, peserta didik, orang tua, dan unsur terkait) tidak mengetahui secara jelas prestasi yang telah dicapai oleh setiap peserta didik. Misalnya, seorang peserta didik memperoleh angka/nilai lima untuk mata pelajaran Bahasa Indonesia, maka yang menjadi pertanyaan adalah apakah angka lima tersebut merupakan hasil penguasaan kompetensi mendengarkan, berbicara, membaca, atau menulis?

Ketidakjelasan ini perlu dibenahi oleh penyelenggara pendidikan agar ke depan, orang tua peserta didik maupun unsur terkait lainnya dapat memahami secara jelas prestasi setiap peserta didik. Para pemerhati pendidikan, antara lain: Prof. Habibie ketika menjabat Menteri Riset dan Teknologi dan Prof. Slamet Imam S. sebagai Rektor Universitas Indonesia mempertanyakan kualitas soal yang disajikan kepada peserta didik. 
Menurutnya, soal-soal ulangan didominasi oleh pilihan ganda dan benar-salah termasuk untuk Evaluasi Belajar Tahap Akhir Nasional (EBTANAS). Lebih lanjut, bentuk soal-soal seperti itu hanya menuntut aspek kognitif tingkat rendah. Pada hakikatnya, soal yang disajikan kurang menuntut peserta didik memiliki kemampuan yang tinggi. Oleh karena itu, disarankan untuk diubah dengan bentuk essay agar peserta didik memiliki tingkat pemahaman dan kompetensi yang lebih tinggi. Saran tersebut ditanggapi oleh para pemangku kepentingan dalam bentuk pro dan kontra. Pihak yang berseberangan (kontra) mengatakan bahwa guru akan mengalami kesulitan dalam memeriksanya. Pemerintah merespon saran tersebut dengan melakukan perubahan/penyempurnaan melalui pengembangan kompetensi yang harus dikuasai oleh setiap peserta didik pada setiap jenis dan jenjang pendidikan. Bentuk konkrit tanggapan Pemerintah antara lain mengadakan perubahan kurikulum pada jenjang pendidikan dasar dan menengah, yaitu melalui penyempurnaan Kurikulum 1994 menjadi Kurikulum Berbasis Kompetensi (KBK) 2004 yang kemudian menjadi Standar Isi (SI)

Bersamaan dengan perubahan kurikulum tersebut, sejak awal proses penyusunan KBK 2004 terjadi paradigma baru tentang pentingnya perubahan dalam cara menilai prestasi peserta didik yang kemudian paradigma tersebut dianggap sesuai dan mendukung pelaksanaan KBK. Pedoman pelaksanaan penilaian dimaksud dinamakan "Pedoman Penilaian Kelas 2004". Pada intinya, guru disarankan untuk menggunakan berbagai teknik dalam melaksanakan penilaian terhadap peserta didik serta menggunakan model penilaian yang lebih rinci. Agar pelaksanaan KBK berjalan sesuai dengan tuntutan kompetensi maka kemudian KBK dan Pedoman Penilaian Kelas disempurnakan oleh badan independen yaitu Badan Standar Nasional Pendidikan (BSNP). Selanjutnya, dokumen tersebut disahkan dengan diberi nama KBK menjadi Standar Isi (SI 2006) dan Pedoman Penilaian Kelas menjadi Standar Penilaian Pendidikan (SPP) 2007 di mana keduanya merupakan bagian dari delapan Standar Nasional Pendidikan (SNP) yang berlaku saat ini.

Pada hakikatnya inti dari KBK dan SI relatif sama. Keduanya menuntut peserta didik untuk mencapai kompetensi, paling tidak, yang tercantum dalam SI. Begitu pula dengan Pedoman Penilaian Kelas dan SPP, keduanya sama-sama difokuskan pada bagaimana seharusnya melaksanakan proses penilaian terhadap peserta didik dengan menekankan penggunaan berbagai teknik yang disesuaikan dengan kompetensi yang harus dicapai peserta didik.

Standar Isi 2006 berlaku pada jenjang pendidikan dasar dan menengah sesuai dengan: a) Undang-Undang Nomor: 20/2003 Tentang Sistem Pendidikan Nasional (UUSPN), b) Peraturan Pemerintah (PP) 19/2005, dan c) Peraturan Menteri Pendidikan Nomor. 22, 23, dan 24, Tahun 2006. SI tahun 2006 terdiri atas beberapa komponen, antara lain: struktur program, beban belajar, kalender pendidikan, Standar Kompetensi (SK) dan Kompetensi Dasar (KD), serta Kurikulum Tingkat Satuan Pendidikan (KTSP) yang disusun oleh setiap satuan pendidikan. Selanjutnya, KTSP terdiri atas beberapa komponen, antara lain: silabus dan rencana pelaksanaan pembelajaran (RPP). Silabus dan RPP terdiri atas SK dan KD yang telah ditetapkan dalam SI. RPP ditambah dengan kegiatan pembelajaran secara rinci sebagai jabaran dari KD dan proses penilaian yang merujuk pada Permendiknas Nomor 20/2007.

Kompetensi pada mata pelajaran Bahasa Indonesia pada Standar Isi (SI) 2006 dinyatakan bahwa setiap peserta didik dituntut untuk memiliki empat kategori kompetensi berbahasa, yaitu: 1) mendengarkan, 2) berbicara, 3) membaca, dan 4) menulis. Sejak Tahun 2009, sebagian SD di beberapa kabupaten dan kota di provinsi yang berbeda menggunakan model penilaian yang bervariasi, mulai dari yang sederhana sampai ke yang lebih kompleks. Kompleks artinya penilaian dilaksanakan terhadap empat kategori kompetensi berbahasa Indonesia.

Permasalahan yang ada antara lain bahwa penggunaan model yang sederhana tidak menggambarkan secara jelas pencapaian kategori kompetensi berbahasa Indonesia oleh peserta didik. Kondisi ini dikhawatirkan akan berpengaruh pada SD lainnya sehingga akan kembali ke sistem penilaian lama di mana yang diukur bukan penguasaan berbagai kompetensi, namun penguasaan berbagai konsep. 
Tujuan penulisan artikel ini adalah untuk mensosialisasikan gagasan tentang penggunaan model penilaian Bahasa Indonesia yang ideal untuk mendukung pelaksanaan kurikulum sekolah dasar secara optimal.

\section{Kajian Literatur dan Pembahasan}

Pendidikan adalah usaha sadar dan terencana untuk mewujudkan suasana belajar dan proses pembelajaran agar peserta didik secara aktif mengembangkan potensi dirinya untuk memiliki kekuatan spiritual keagamaan, pengendalian diri, kepribadian, kecerdasan, akhlak mulia, serta keterampilan yang diperlukan dirinya, masyarakat, bangsa dan negara (UUSPN/2003. Dengan kata lain, Pemerintah mengharapkan setiap peserta didik memiliki kompetensi/keterampilan yang harus dikuasai oleh setiap peserta didik sehingga menggambarkan secara objektif kualitas performance para tamatan satuan pendidikan.

Selanjutnya, PP Nomor 19/2005 tentang penilaian yang tercantum pada Bab IV Pasal 22, ayat: (1) dan Permendiknas Nomor 20/2007 tentang Penilaian, huruf $\mathrm{C}$ tentang Teknik dan Instrumen Penilaian, butir 1 dinyatakan bahwa "Penilaian hasil belajar oleh pendidik menggunakan berbagai teknik penilaian berupa tes, observasi, penugasan perseorangan atau kelompok, dan bentuk lain yang sesuai dengan karakteristik kompetensi dan tingkat perkembangan peserta didik". Teknik tes meliputi "tes tertulis, tes lisan, dan tes praktik atau tes kinerja" (butir 2) dan "teknik observasi atau pengamatan dilakukan selama pembelajaran berlangsung dan/ atau di luar kegiatan pembelajaran" (butir 3). Teknik observasi dan praktik sama-sama memerlukan waktu lama dalam pelaksanaannya. Namun demikian, keduanya menjadi penting karena dengan mengadakan observasi dan peserta didik mengadakan praktik guru akan memperoleh informasi yang objektif "tentang sejauh mana hasil belajar peserta didik atau ketercapaian kompetensi peserta didik" (Akhmad Sudrajat, 2008.)

\section{Kompetensi Dalam Standar Isi (SI)}

Pemerintah menyusun dan memetakan SK dan KD minimal untuk semua mata pelajaran yang ada di lingkup pendidikan dasar dan menengah wajib menyampaikannya kepada peserta didik agar setelah lulus mereka memiliki berbagai kompetensi yang telah ditentukan tersebut. Minimal artinya suatu sekolah, karena alasan tertentu, diperbolehkan menambah kompetensi tetapi jangan menghilangkan yang sudah ada. Yang dimaksud dengan kompetensi adalah perpaduan antara pengetahuan, keterampilan dan sikap"competence...encompasses a combination of knowledge, skills and behaviour utilized to improve performance" (WIKIPEDIA, 2009a)

Kompetensi-kompetensi minimal yang ada dalam SI (Permendiknas Nomor 22/2006) yang harus dicapai peserta didik dalam lingkup pendidikan dasar dan menengah dipetakan oleh Pemerintah dan dikategorikan berdasarkan satuan pendidikan, kelas, semester, mata pelajaran, SK dan KD. Berikut adalah contoh gambaran SK dan KD minimal dimaksud untuk mata pelajaran Bahasa Indonesia kelas IV semester 1.

Oleh karena suatu sekolah diperbolehkan menambah kompetensi, maka terlihat ada kebebasan bagi setiap SD untuk menentukan kuantitas kompetensi yang harus dicapai oleh peserta didiknya. Berangkat dari kebebasan ini, pada akhirnya suatu SD akan memiliki KTSP serta silabus dan RPP yang berbeda dengan yang dimiliki oleh SD lain yang terdekat. Kondisi ini juga mendorong adanya perbedaan mutu lulusan dari satu sekolah dengan sekolah lainnya.

\section{Jabaran Standar Isi (SI)}

Dalam upaya mengembangkan SK, KD, dan SI, dalam pembelajaran di kelas, sebaiknya menjabarkan secara sistimatik. Pertama guru, kepala sekolah dan komite sekolah secara bersama menyusun kurikulum sekolah berdasarkan SI yang disesuaikan dengan kepentingan daerah dan lingkungan sekolah, dan kurikulum ini dikenal dengan Kurikulum Tingkat Satuan Pendidikan yang dikenal dengan KTSP atau School-Based Curriculum. "In Practice, SchoolBased Curriculum Development can range from individual teachers interpreting and adapting existing curricula to whole staff working together to create curricula, sometimes with input from students, or people from outside the school" (Rachel Bolstad, 2004). 
Tabel 1. Kompetensi Bahasa Indonesia, Kelas IV, Semester 1

\begin{tabular}{|c|c|}
\hline Standar Kompetensi (SK) & Kompetensi Dasar (KD) \\
\hline $\begin{array}{l}\text { 1. Mendengarkan } \\
\text { Mendengarkan } \\
\text { penjelasan tentang } \\
\text { petunjuk denah dan } \\
\text { simbol daerah/lambang } \\
\text { korps }\end{array}$ & $\begin{array}{l}\text { 1.1 Membuat gambar/denah berdasarkan penjelasan yang } \\
\text { didengar } \\
1.2 \text { Menjelaskan kembali secara lisan atau tulis penjelasan } \\
\text { tentang simbol daerah/lambang korps }\end{array}$ \\
\hline $\begin{array}{l}\text { 2. Berbicara } \\
\text { Mendeskripsikan secara } \\
\text { lisan tempat sesuai } \\
\text { denah dan petunjuk } \\
\text { penggunaan suatu alat }\end{array}$ & $\begin{array}{l}2.1 \text { Mendeskripsikan tempat sesuai dengan denah atau } \\
\text { gambar dengan kalimat yang runtut } \\
\text { 2.2 Menjelaskan petunjuk penggunaan suatu alat dengan } \\
\text { bahasa yang baik dan benar }\end{array}$ \\
\hline $\begin{array}{l}\text { 3. Membaca } \\
\text { Memahami teks agak } \\
\text { panjang (150-200 } \\
\text { kata), petunjuk } \\
\text { pemakaian, makna kata } \\
\text { dalam } \\
\text { kamus/ensiklopedi }\end{array}$ & $\begin{array}{l}\text { 3.1 Menemukan pikiran pokok teks agak panjang (150-200 } \\
\text { kata) dengan cara membaca sekilas } \\
\text { 3.2 Melakukan sesuatu berdasarkan petunjuk pemakaian } \\
\text { yang dibaca } \\
\text { 3.3 Menemukan makna dan informasi secara tepat dalam } \\
\text { kamus/ensiklopedi melalui membaca memindai. }\end{array}$ \\
\hline $\begin{array}{l}\text { 4. Menulis } \\
\text { Mengungkapkan pikiran, } \\
\text { perasaan, dan informasi } \\
\text { secara tertulis dalam } \\
\text { bentuk percakapan, } \\
\text { petunjuk, cerita, dan } \\
\text { surat }\end{array}$ & 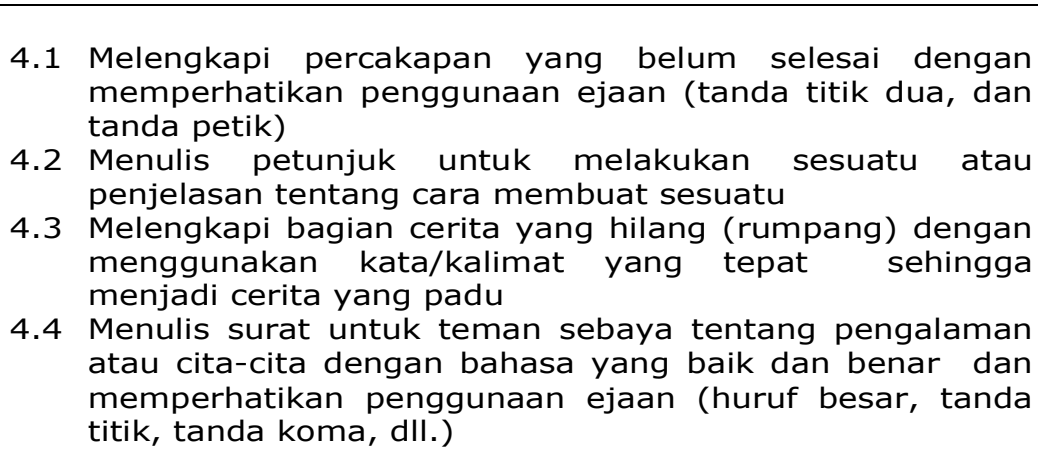 \\
\hline
\end{tabular}

KTSP ini mencakup beberapa komponen termasuk silabus untuk semua mata pelajaran. Keberadaan silabus penting karena akan bermanfaat sebagai "pedoman bagi pengembangan pembelajaran lebih lanjut"(Yahya Nursidik, 2009), yaitu penyusunan RPP. RPP atau lesson plan meliputi penjelasan lebih rinci daripada uraian di silabus, sehingga di dalam lesson plan benarbenar menggambarkan kegiatan yang akan dilaksanakan di dalam kelas-"a lesson plan is a teacher's detailed description of the course of instruction for an individual lesson"(WIKIPEDIA, 2009b). Lesson plan dapat juga di definisikan sebagai "an organized outline for a single instructional period. It is a necessary guide for the instructor in that it tells what to do, in what order to do it, and what procedure to use in teaching the material of a lesson"(Google, 2003).
Contoh Silabus Bahasa Indonesia kelas IV, Semester Satu.

Aspek: Mendengarkan, Berbicara, Membaca, dan Menulis

\section{Standar Kompetensi:}

Mendengarkan: Mendengarkan penjelasan tentang petunjuk denah dan simbol daerah/ lambang korps.

Berbicara: Mendeskripsikan secara lisan tempat sesuai denah dan petunjuk penggunaan suatu alat.

Membaca: Memahami teks agak panjang (150200 kata), petunjuk pemakaian, makna kata dalam kamus/ensiklopedi.

Menulis: Mengungkapkan pikiran, perasaan, dan informasi secara tertulis dalam bentuk percakapan, petunjuk, cerita, dan surat. 


\begin{tabular}{|c|c|c|c|c|c|c|}
\hline Kompetensi Dasar & $\begin{array}{l}\text { Materi } \\
\text { Pembe- } \\
\text { lajaran }\end{array}$ & Kegiatan Pembelajaran & Indikator & $\begin{array}{l}\text { Penilai } \\
\text { an }\end{array}$ & $\begin{array}{l}\text { Alo- } \\
\text { kasi } \\
\text { Wak } \\
\text { tu }\end{array}$ & $\begin{array}{l}\text { Sumber/ } \\
\text { Bahan } \\
\text { Ajar }\end{array}$ \\
\hline $\begin{array}{l}\text { 1.1 Membuat } \\
\text { gambar/denah } \\
\text { berdasarkan } \\
\text { penjelasan yang } \\
\text { didengar } \\
2.1 \text { Mendeskripsikan } \\
\text { tempat secara lisan } \\
\text { sesuai dengan denah } \\
\text { atau gambar dengan } \\
\text { kalimat yang runtut } \\
\text { 3. } 2 \text { Melakukan } \\
\text { sesuatu berdasarkan } \\
\text { petunjuk pemakaian } \\
\text { yang dibaca } \\
4.2 \text { Menulis petunjuk } \\
\text { untuk melakukan } \\
\text { sesuatu atau } \\
\text { penjelasan tentang } \\
\text { cara membuat } \\
\text { sesuatu }\end{array}$ & $\begin{array}{l}\text { Denah } \\
\text { suatu } \\
\text { tempat }\end{array}$ & $\begin{array}{l}\text { - Mendengarkan } \\
\text { penjelasan tentang } \\
\text { cara membaca } \\
\text { denah } \\
\text { - Berpasangan } \\
\text { berdialog secara lisan } \\
\text { menceriterakan } \\
\text { tentang cara menuju } \\
\text { ke suatu tempat } \\
\text { yang ditentukan } \\
\text { - Membaca beberapa } \\
\text { teks tentang cara } \\
\text { menuju ke beberapa } \\
\text { tempat/ lokasi } \\
\text { - Menulis beberapa pa- } \\
\text { ragraf memberitahu- } \\
\text { kan kepada teman } \\
\text { satu kelas cara } \\
\text { menuju ke suatu } \\
\text { tempat }\end{array}$ & $\begin{array}{l}\text { - Mendeskrip } \\
\text { sikan } \\
\text { secara lisan } \\
\text { dan tulisan } \\
\text { tentang } \\
\text { denah } \\
\text { - Memahami } \\
\text { teks tertulis } \\
\text { dengan } \\
\text { menjawab } \\
\text { beberapa } \\
\text { pertanyaan } \\
\text { yang di- } \\
\text { ajukannya }\end{array}$ & $\begin{array}{l}\text { Tes } \\
\text { lisan } \\
\text { dan } \\
\text { tertulis }\end{array}$ & & $\begin{array}{l}\text {-Denah } \\
\text { sekolah } \\
\text {-Buku } \\
\text { Bahasa } \\
\text { Indonesia } \\
\text { kelas IV }\end{array}$ \\
\hline
\end{tabular}

Contoh RPP Bahasa Indonesia Kelas IV:

Semester : Satu

Waktu : $2 \times 30$ menit

Aspek : Mendengarkan, Berbicara, Membaca, dan Menulis

Tujuan Pembelajaran: Peserta didik dapat memahami, dan menjelaskan secara lisan dan tulisan tentang denah sekolah dan kelas.

\section{Standar Kompetensi}

Mendengarkan: Mendengarkan penjelasan tentang petunjuk denah dan simbol daerah/ lambang korps

Berbicara: Mendeskripsikan secara lisan tempat sesuai denah dan petunjuk penggunaan suat alat.

Membaca: Memahami teks agak panjang (150200) kata, petunjuk pemakaian, makna kat dalam kamus/ensiklopedia.

Menulis: Mengungkapkan pikiran, perasaan, dan informasi secara tertulis dalam bentuk percakapan, petunjuk, cerita, dan surat

\section{Kompetensi Dasar}

Kompetensi dasar dimaksud terdiri atas: 1) Membuat gambar/denah berdasarkan penjelasan yang didengar; 2) Mendeskripsikan gambar/denah secara lisan sesuai dengan denah/gambar yang diperlihatkan; 3) Melakukan sesuatu berdasarkan petunjuk yang dibaca; 4) Menulis petunjuk untuk melakukan sesuatu atau penjelasan tentang cara membuat sesuatu (Materi Pembelajaran: Denah sekolah dan kelas)

\section{Kegiatan Pembelajaran}

Kegiatan Awal pembelajaran dilakukan dengan mengadakan apersepsi, bertanya tentang alamat rumah mereka. Kemudian, dilanjutkan dengan Kegiatan Inti, yang mencakup: 1) Peserta didik mendengarkan penjelasan tentang suatu denah, kemudian mereka membuat denah berdasarkan penjelasan tersebut; 2) Peserta didik menerima denah lain yang berbeda-beda, kemudian menceriterakannya secara lisan kepada teman; 3) Secara berpasangan peserta didik membaca petunjuk sederhana yang berbeda dengan pasangan lain untuk membuat suatu denah; 4) Denah yang dibuat dijelaskan secara lisan kepada pasangan lain; 5) Peserta didik ditugaskan untuk mengamati lokasi sekolah dan kelas mereka seandainya mereka masuk dari luar sekolah; 6) Secara individu mereka membuat petunjuk tertulis tentang lokasi sekolah, dan kelas mereka yang 
ditujukan kepada teman mereka masing-masing yang dianggap belum pernah datang ke sekolah mereka.

Kegiatan Akhir, meliputi: 1) Peserta didik dan guru mengadakan refleksi tentang proses belajar yang baru dilakukan dan 2) Peserta didik ditugaskan untuk menulis satu paragraf tentang lokasi kelas lain dengan kata dan kalimat serta tanda baca yang benar. Selanjutnya, Indikator harus tercermin dalam: a) Mendeskripsikan secara lisan dan tulisan tentang denah sekolah dan kelas, dan b) Memahami teks tertulis tentang denah dengan menjawab beberapa pertanyaannya. Adapun, aspek penilaian, mencakup: Tes lisan dan tes tulis; sedangkan Metode Pembelajaran dengan menggunakan Ceramah dan penugasan, dan di lengkapi dengan Sumber Belajar: Gambar Denah, dan Buku Bahasa Indonesia kelas IV

\section{Kegiatan Pembelajaran}

Pada tahap pelaksanaan, guru disarankan melaksanakan kegiatan pembelajaran dengan memberi kesempatan kepada peserta didik untuk terlibat aktif secara maksimal dan mengarah pada pencapaian kompetensi yang ditentukan. Pada akhir pembelajaran mereka tidak hanya memahami konsep, melainkan juga mengalami sendiri untuk melakukan sesuatu agar kompetensi yang menjadi targetnya tercapai secara matang. Sebaliknya, apabila guru dominan memberi ceramah dan peserta didik hanya mendengarkan, mereka akan sulit untuk mencapai kompetensi yang diharapkan. Ada pepatah yang mengatakan: We listen we forget, We see we remember, We do we understand.

Apabila guru berceritera dan peserta didik hanya mendengarkan, mereka akan cepat lupa isi dari ceriteranya. Apabila mereka hanya melihat guru yang melakukan/mendemonstrasikan sesuatu, hasilnya mereka hanya akan ingat. Apabila mereka diberi kesempatan untuk melakukan, mengamati sendiri, mereka akan mengerti. Itulah makna pepatah tersebut dan hal ini relevan dengan kebijakan Pemerintah yang dituangkan dalam SNP melalui standar proses.

Ada beberapa karakteristik kegiatan pembelajaran yang berpusat pada peserta didik, antara lain "1) guru lebih berperan sebagai fasilitator dalam kegiatan pembelajaran daripada sebagai penyaji pengetahuan, 2) pengelolaan kelas yang lebih kondusif terhadap kegiatan dan interaksi peserta didik yang mengarah pada pengalaman belajar yang produktif, dan 3) peserta didik aktif dalam kegiatan yang berkaitan dengan pembelajaran daripada hanya duduk manis dan pasif selama kegiatan belajar berlangsung di dalam kelas."(Sudirman Siahaan, 2008). Selanjutnya, kegiatan pembelajaran Bahasa Indonesia yang melibatkan peserta didik aktif dan kreatif menuju ke tercapainya berbagai kompetensi minimal berbahasa yang ada dalam SI dan KTSP akan mengubah fenomena peserta didik dari pasif menjadi aktif, dari arah kegiatan pembelajaran yang kurang jelas menjadi lebih jelas. Namun, perlu disadari bahwa perubahan ini tidak akan menjamin pelaksanaan SI dan KTSP berlangsung berkelanjutan. Oleh karena itu, perlu didukung oleh adanya aspek lain yang dianggap mendasar dan signifikan dalam mendukung pelaksanaan SI dan KTSP, yaitu model penilaian yang sesuai.

\section{Ilustrasi Proyek Cara Belajar Siswa Aktif (CBSA)}

Hasil penelitian tentang CBSA menunjukkan adanya keterlibatan peserta didik yang cukup tinggi dalam proses pembelajaran. Berikut disajikan tiga contoh kegiatan yang dapat direkam. Misalnya untuk mata pelajaran Bahasa Indonesia, guru menugaskan peserta didik untuk membentuk kelompok kecil dan mengamati tumbuhan yang ada di sekitar sekolah selama beberapa menit. Setelah itu mereka dianjurkan membuat suatu sajak berdasarkan catatan pengamatan mereka. Kemudian, mereka membacakan sajak di depan kelas. Selanjutnya, peserta didik melaksanakan seminar mini di kelas mereka. Di antara mereka ada yang menjadi penceramah, moderator, ada yang bertanya, dan menjawab pertanyaan. Kemudian diakhiri dengan peserta didik mewawancarai bapak RT, dan Polisi pada waktu yang berbeda. Kemudian hasil wawancaranya ditulis secara baik, kemudian dilaporkan secara lisan di depan kelas. Beberapa contoh kegiatan tersebut menggambarkan adanya kecenderungan fokus perhatian guru kepada peserta didik atau diistilahkan dalam 
bahasa Inggris Child Centered. "child centered adalah sistem pembelajaran dimana fokus pembelajaran adalah dengan pelajar, bukan guru. Guru sebagai fasilitator atau manager proses pembelajaran"(Phillip Rekdale,2008). Jadi "proses pembelajaran aktivitasnya dalam bentuk interaksi belajar mengajar dalam suasana interaksi edukatif, yaitu interaksi yang sadar akan tujuan..."(Damajanti Kusuma Dewi, 2009).

Pada waktu yang bersamaan SD yang mengikuti proyek CBSA tetap harus menggunakan model penilaian yang pada waktu itu dirancang oleh pusat yang mencakup satu angka untuk satu mata pelajaran dan tidak ada ruangan yang dapat mengakomodir nilai untuk aspek keterlibatan, kreativitas dan pencapaian kompetensi peserta didik. Hal ini terjadi karena pada waktu itu belum tersentuh oleh wacana agar keterlibatan, kreatifitas dan pencapaian kompetensi oleh peserta didik layak diberi penghargaan dari guru/ sekolah dalam bentuk nilai atau deskripsi baik sebagai hasil dari ulangan/tes harian maupun hasil ujian nasional. Penilaian pada waktu itu secara jelas menekankan ketercapaian penguasaan konsep-konsep. Indikasinya baik di dalam ulangan harian maupun ujian nasional terjadi dominasi soal dalam bentuk pilihan ganda dan atau benar salah. Dari hasil wawancara dengan guru kelas di SD-CBSA "sistem penilaian dengan model penilaian yang sederhana, satu angka untuk satu mata pelajaran kurang memotivasi guru untuk melaksanakan CBSA secara maksimal dan berkelanjutan mengingat pelaksanaan dan tuntutan yang berbeda. Jadi sistem penilaian memiliki pengaruh kuat terhadap pelaksanaan kegiatan belajar di kelas" (Ambari Sutardi, 1992).

Simpulan dari ilustrasi di atas adalah pelaksanaan CBSA di SD yang menjadi objek penelitian dapat dikatakan baik karena adanya keterlibatan peserta didik yang tinggi untuk aktif dan kreatif selama pembelajaran berlangsung. Kekhasan dari CBSA ini cukup baik dalam mengembangkan gagasan dan kreatifitas peserta didik, namun pada kenyataannya hal ini tidak terekam karena pihak sekolah harus menggunakan model penilaian yang sederhana dan berlaku secara nasional di mana aspek keterlibatan dan kreatifitas peserta didik tidak tergambar di dalam buku rapor. Hal ini, menurut guru yang diwawancarai, adalah salah satu penyebab sulitnya bagi mereka untuk melaksanakan dan mempertahankan proyek tersebut. Karena itu dapat dikatakan bahwa model penilaian yang digunakan memiliki pengaruh kuat terhadap pelaksanaan inovasi kegiatan pembelajaran.

\section{Proses Penilaian}

Kuatnya pengaruh sistem penilaian perlu dijadikan bahan pertimbangan di dalam mendukung pelaksanaan SI dan KTSP. Di tingkat kebijakan yang tertuang dalam Lampiran Permendiknas Nomor 20, Tanggal 11 Juni 2007 tentang Standar Penilaian Pendidikan dijelaskan bagaimana sebaiknya melaksanakan proses penilaian yang sesuai dengan tuntutan SK dan KD. Seperti dipaparkan di atas, SK dan KD bervariasi dan dituntut untuk dicapai peserta didik. Untuk mengetahui apakah tercapai atau tidak, guru perlu menggunakan berbagai teknik penilaian yang sesuai. Karena itu, pelaksana di lapangan diharuskan menggunakan berbagai teknik penilaian yang sesuai dengan tuntutan kompetensi. Dengan menggunakan berbagai teknik, prosesnya lebih kompleks baik dalam tahap persiapan (penyusunan kisi-kisi dan soal), pelaksanaan maupun perekaman hasil penilaian. Misalnya pada tahap persiapan, pelaksana harus mempersiapkan berbagai instrumen penilaian. Pada tahap pelaksanaan, untuk memberi nilai satu aspek, misalnya aspek kinerja peserta didik, guru dituntut untuk mengamati mereka satu per satu. Guna menilai keterampilan berbicara dan kebiasaan mereka baik di dalam maupun di luar lingkungan sekolah yang tidak terpantau, guru dituntut untuk mengadakan wawancara satu per satu. Ketika akan menilai aspek kerja sama dengan teman, ketelitian, perencanaan, pelaksanaan dan penyajian hasil, guru dituntut untuk memberi tugas/proyek dan mengamatinya mulai dari perencanaan, pelaksanaan dan penyajian hasilnya. Bila akan menilai apakah ada atau tidak kemajuan dalam membuat karya tulis, guru harus mengumpulkan beberapa karya tulis mereka, kemudian dianalisis guna mengetahui ada tidaknya kemajuan belajarnya. Walaupun berbagai teknik, ini tidak serta merta harus digunakan secara simultan untuk menilai pencapaian satu kompetensi, namun semuanya akan memerlukan ekstra waktu, tenaga dan perhatian. 


\section{Kesiapan sekolah}

Hasil penelitian yang dilaksanakan oleh Pusat Kurikulum pada akhir pengembangan KBK 2004 menunjukkan bahwa responden guru SD telah mengikuti penataran tentang penilaian berbasis kelas dan sebagian dari mereka merasa lebih sulit untuk melaksanakan model penilaian yang baru tersebut karena mereka menganggap lebih kompleks dalam merancang instrumen, melaksanakan penilaian, dan merekam nilai ke dalam buku rapor. Kondisi ini nampaknya berlanjut ketika penulis mengadakan sosialisasi tentang SI umumnya dan workshop tentang KTSP di beberapa kabupaten dan kota khususnya selama tahun 2007 dan 2008. Fenomena ini oleh para penentu kebijakan baik di pusat maupun di daerah jangan dijadikan hambatan dalam mendukung pelaksanaan SI dan KTSP. Sebaliknya, dijadikan tantangan untuk lebih proaktif dalam membantu unsur terkait di daerah dalam melaksanakan sistem penilaian sesuai dengan aturan yang berlaku (SNP) yang tertuang di dalam lampiran Permendiknas Nomor 20, Tahun 2007, mulai dari menyusun kisi-kisi, penyusunan butir-butir soal berbasis kompetensi serta merancang buku rapor yang dapat mengakomodasi berbagai nilai yang menggambarkan pencapaian kompetensi oleh peserta didik.

\section{Keanekaragaman format rapor sekolah}

Belum diperoleh informasi secara tertulis yang menyatakan bahwa setiap SD berwenang merancang buku rapor sendiri. Namun, pada kenyataan di lapangan hingga akhir tahun 2008, yang merancang buku rapor di daerah berbedabeda dari satu daerah dengan daerah lainnya. Misalnya, di suatu provinsi, buku rapor SD disusun oleh Dinas Pendidikan tingkat provinsi. Di provinsi yang berbeda penyusunannya diserahkan ke setiap kabupaten/kota, dan belum ditemukan suatu SD memiliki rancangan rapor sendiri. Sebagai konsekuensinya data menunjukkan ada beberapa model rapor SD yang berbeda yang diperoleh dari beberapa kabupaten/kota, namun pada tulisan ini hanya dipaparkan tiga model.

Model 1 penampilannya sangat sederhana, hanya meliputi satu angka untuk satu mata pelajaran serta nilai rata-rata kelas, dan ini model yang telah berlaku secara nasional selama bertahun-tahun sebelum ada KBK 2004 dan SI 2006. Seperti dipahami bahwa model penilaian dapat dijadikan tuntutan bagi guru/pihak sekolah untuk melaksanakan pembelajaran dan juga dapat digunakan sebagai gambaran pencapaian prestasi peserta didik. Karena itu model 1 dapat juga dipahami oleh sebagian guru untuk menyusun kisi-kisi dan butir-butir soal serta pelaksanaan penilaiannya hanya melalui paper and pen test dengan dominasi soal pilihan ganda dan benar - salah seperti ketika berlaku kurikulum 1994 dan sebelumnya.

Ada beberapa kemungkinan alasan kenapa sebagian SD menggunakan model 1 . Pertama, sekolah belum memahami ruh dari perubahan kurikulum hingga menjadi SI 2006. Kedua, sekolah harus menerima dan menggunakan model yang ada dari instansi yang berwenang di daerah mereka yang juga kurang memahami ruh tersebut. Ketiga, pihak sekolah belum memiliki dana yang cukup untuk membuat sendiri buku rapor yang sesuai dengan tuntutan SI dan KTSP. Keempat, karena ada petunjuk di dalam SNP melalui standar penilaian yang tertuang pada butir 13 bagian $D$ tentang mekanisme dan prosedur penilaian yang menegaskan bahwa nilai yang dituangkan di dalam rapor satu angka untuk satu mata pelajaran. Sementara itu, di bagian lain di dalam standar tersebut tepatnya pada bagian C. Ten-

Format Rapor Model 1.

\begin{tabular}{|l|l|l|l|}
\hline No. & \multicolumn{1}{|c|}{ Mata Pelajaran } & Nilai & Nilai rata-rata kelas \\
\hline 1. & Pendidikan Agama & & \\
\hline 2. & Pend. Kewarganegaraan & & \\
\hline 3. & Bahasa Indonesia & & \\
\hline 4. & Matematika & & \\
\hline 5. & Pengetahuan Alam & & \\
\hline 6. & Kerajinan Tangan dan Kesenian & & \\
\hline 7. & Pendidikan Jasmani yang & & \\
\hline 8. & Muatan Lokal & & \\
\hline
\end{tabular}

Jumlah Nilai Prestasi Hasil Belajar:. 
Format rapor Model 2

\begin{tabular}{|l|l|l|l|l|}
\hline No & \multicolumn{1}{|c|}{ Mata Pelajaran } & \multirow{2}{*}{ KKM } & \multicolumn{2}{|c|}{ Nilai } \\
\cline { 4 - 5 } & & & Angka & Huruf \\
\hline 1. & Pendidikan Agama & & & \\
\hline 2. & $\begin{array}{l}\text { Pendidikan } \\
\text { Kewarganegaraan }\end{array}$ & & & \\
\hline 3. & Bahasa Indonesia & & & \\
\hline 4. & Matematika & & & \\
\hline 5. & Pengetahuan Alam & & & \\
\hline 6. & $\begin{array}{l}\text { Kerajinan Tangan dan } \\
\text { Kesenian }\end{array}$ & & & \\
\hline 7. & Pendidikan Jasmani & & & \\
\hline 8. & Muatan Lokal & & & \\
\hline
\end{tabular}

Format Rapor Model 3

\begin{tabular}{|c|c|c|c|}
\hline No. & Mata Pelajaran & Aspek Penilaian & Angka \\
\hline \multirow[t]{2}{*}{1.} & \multirow[t]{2}{*}{ Pendidikan Agama } & Penguasaan Konsep dan nilai-nilai & \\
\hline & & Penerapan & \\
\hline \multirow[t]{2}{*}{2.} & \multirow{2}{*}{$\begin{array}{l}\text { Pendidikan } \\
\text { Kewarganegaraan }\end{array}$} & Penguasaan Konsep dan nilai-nilai & \\
\hline & & Penerapan & \\
\hline \multirow[t]{4}{*}{3.} & \multirow[t]{4}{*}{ Bahasa Indonesia } & Mendengarkan & \\
\hline & & Berbicara & \\
\hline & & Membaca & \\
\hline & & Menulis & \\
\hline \multirow[t]{3}{*}{4.} & \multirow[t]{3}{*}{ Matematika } & Pemahaman Konsep & \\
\hline & & Penalaran dan Komunikasi & \\
\hline & & Pemecahan masalah & \\
\hline \multirow[t]{2}{*}{5.} & \multirow[t]{2}{*}{$\begin{array}{l}\text { Ilmu Pengetahuan } \\
\text { Alam }\end{array}$} & $\begin{array}{l}\text { Pemahaman dan penerapan } \\
\text { konsep }\end{array}$ & \\
\hline & & Kinerja Ilmiah & \\
\hline \multirow[t]{2}{*}{6} & \multirow{2}{*}{$\begin{array}{l}\text { Ilmu Pengetahuan } \\
\text { Sosial }\end{array}$} & Penguasaan Konsep & \\
\hline & & Penerapan & \\
\hline \multirow[t]{2}{*}{7} & \multirow{2}{*}{$\begin{array}{l}\text { Seni Budaya dan } \\
\text { Keterampilan }\end{array}$} & Apresiasi & \\
\hline & & Kreasi & \\
\hline \multirow[t]{4}{*}{8} & \multirow{4}{*}{$\begin{array}{l}\text { Pendidikan Jasmani, } \\
\text { Olahraga dan } \\
\text { Kesehatan }\end{array}$} & Kemampuan gerak dasar & \\
\hline & & Keterampilan cabang olahraga & \\
\hline & & Kebugaran dan kesehatan & \\
\hline & & $\begin{array}{l}\text { Pilihan: Akuatik/Pend.Luar Satuan } \\
\text { pendidikan }\end{array}$ & \\
\hline 9. & Muatan Lokal.......... & & \\
\hline
\end{tabular}

tang Teknik dan Instrumen Penilaian dinyatakan penilaian menggunakan multi-teknik yang juga ditegaskan di dalam PP Nomor 19 tentang penilaian yang tercantum di dalam Bab IV Pasal 22 , ayat 1.

Hasil wawancara dengan beberapa penentu kebijakan di daerah mengatakan bahwa, pernyataan "menggunakan multiteknik dalam pelaksanaan penilaian" dan "satu nilai untuk satu mata pelajaran di dalam buku rapor" yang tertuang di dalam satu kebijakan menyulitkan pelaksana di lapangan karena dirasa kontradiktif. Menjadi kontradiktif karena pemahaman mereka dengan menggunakan multiteknik akan menghasilkan lebih dari satu nilai untuk satu mata pelajaran dan pola ini akan menggambarkan pencapaian prestasi peserta didik yang sesungguhnya (Model 3). Masih menjadi kontradiktif dengan "penggunaan multiteknik" apabila para pelaksana ingin melaksanakan prinsip satu nilai 
untuk satu mata pelajaran (model 1), dan karenanya memungkinkan mereka hanya melaksanakan penilaian dengan paper and pen test.

Tidak menjadi kontradiktif apabila guru/pihak sekolah dapat melaksanakan kedua aturan di atas sehingga pada tahap pelaksanaannya akan terjadi sebagai berikut: mulai dari persiapan, pelaksanaan penilaian hingga penyusunan format perekaman nilai sifatnya ideal dalam arti benarbenar mengarahkan dan mencerminkan penguasaan peserta didik terhadap kompetensi sasaran mereka. Akan tetapi hasil yang tercatat di dalam buku rapor hanya satu angka untuk satu mata pelajaran dengan rumusan sebagai berikut: Nilai Akhir $(N A)=$

$P$ tambah $Q$ per dua $\left(N A=\frac{P+Q}{2}\right)$

Keterangan:

P (nilai perolehan = jumlah nilai ulangan harian+ nilai tugas + nilai proses)

Q (nilai ulangan semester)

Atau menggunakan rumusan lain yang tertera di dalam Materi Pelatihan KTSP 2009 untuk SD, Departemen Pendidikan Nasional sebagai berikut:

\section{$\underline{\text { ULHAR + UTS + UAS + Tugas }}$ \\ 4}

Dengan menggunakan rumusan-rumusan tertentu angka/nilai menjadi satu untuk setiap mata pelajaran dan hasilnya seperti Model 1. Yang menjadi masalah model tersebut tetap tidak dapat menyampaikan informasi kepada pembaca rapor tentang kompetensi yang dicapai oleh peserta didik, dan ini suatu kelemahan. Bila dengan kelemahannya tetap digunakan secara nasional, ada kekhawatiran akan 1) menghilangkan makna transparansi dalam sistem penilaian, 2) mengurangi makna dari tujuan perubahan kurikulum, 3) mengurangi motivasi guru dalam melaksanakan pembelajaran dan proses penilaian sesuai dengan SNP yang tertuang di dalam standar proses dan standar penilaian, 4) mendorong pihak sekolah dalam menyusun soal yang kembali akan didominasi oleh bentuk benarsalah atau pilihan ganda.

Bila kondisi ini berlangsung secara berkesinambungan, suatu saat pelaksanaan SI umumnya, standar proses, standar penilaian serta pelaksanaan KTSP khususnya secara perlahan akan menyimpang dari yang seharusnya dan akan kembali ke pembelajaran model lama, peserta didik pasif dan guru sangat dominan serta pelaksanaan proses penilaian yang sederhana. Apabila, dengan alasan tertentu, instansi atau unsur terkait bersikukuh untuk mencantumkan satu angka untuk satu mata pelajaran di dalam rapor, hal ini dapat dilaksanakannya dengan catatan ketika buku rapor tersebut akan disampaikan kepada peserta didik perlu disertakan nilai asli bagi setiap aspek/kategori kompetensi untuk satu mata pelajaran. Hal ini penting agar pembaca dapat memahami prestasi yang sesungguhnya dari seorang peserta didik dengan mudah.

Model 2 berbeda dari model 1, meliputi kriteria ketuntasan minimal (KKM). Kolom KKM terdiri dari nilai yang ditentukan oleh guru/pihak sekolah pada awal tahun akademik sebelum pelayanan proses belajar berlangsung berdasarkan professional judgment. Penentuan besaran nilai untuk KKM didasarkan pada tiga hal. Pertama, kompetensi peserta didik yang dimiliki sebelum proses pembelajaran berlangsung dan informasinya diperoleh dari unsur terkait, misalnya guru kelas 2 memperoleh informasinya dari guru kelas 1. Kedua, tingkat kompleksitas kompetensi yang menjadi target atau paling tidak kompetensi minimal yang ada di dalam SI terhadap peserta didik. Ketiga, keberadaan sarana di sekolah yang dapat mendukung pelaksanaan pembelajaran. Bagian ketiga tentunya ditentukan melalui diskusi terbuka di dalam rapat yang melibatkan warga sekolah beserta komite sekolah. Manfaat pencantuman nilai KKM di dalam rapor akan dapat diketahui ada tidaknya perbedaan antara nilai berdasarkan asumsi guru/pihak sekolah dan nilai berdasarkan hasil pembelajaran yang diikutinya.

Dalam kondisi transisi saat ini kenyataan di lapangan menunjukkan ada SD yang telah dan belum mencantumkan nilai KKM di rapor sehingga ditemui kasus sebagai berikut. Ada seorang peserta didik pindah ke suatu SD dengan membawa buku rapor yang tidak mencantumkan nilai KKM. Sementara di SD yang akan ditempatinya mencantumkannya, karena perbedaan ini menjadi suatu permasalahan, peserta didik tersebut tidak diterima. Hal ini oleh unsur terkait dianggap sebagai suatu kasus kecil, namun sebaiknya ada petunjuk yang jelas tentang hal itu agar kasus 
seperti itu tidak terulang lagi di masa yang akan datang.

Model 3 nampak lebih kompleks, namun dapat menggambarkan beberapa pencapaian kompetensi peserta didik sehingga dapat dikatakan lebih transparan apalagi model tersebut mencantumkan aspek kinerja/psikomotor peserta didik untuk setiap mata pelajaran. Bagi pembaca pun model ini dapat memberi informasi yang lebih jelas. Untuk mata pelajaran Bahasa Indonesia misalnya, model ini dapat menggambarkan pencapaian hasil belajar peserta didik sesuai dengan tuntutan terhadap mereka seperti yang tertuang di dalam SI, silabus dan RPP. Karena itu, model 3 di dalam tulisan ini dapat dikatakan model rapor yang lebih ideal dalam mendukung pelaksanaan SI dan KTSP.

Model 3 tentunya akan menyulitkan para pelaksana di lapangan khususnya dalam hal persiapan, pelaksanaan serta perekaman nilai, namun di sisi lain ada dampak positif bagi seorang guru. Mereka akan lebih mudah mengetahui dan menentukan materi atau bahan ajar yang lebih tepat bagi peserta didik apabila guru tersebut harus menyelenggarakan program remedial bagi mereka. Seperti disadari bahwa kebijakan pemerintah, khususnya yang berhubungan dengan SI yang kemudian dikembangkan menjadi kurikulum operasional yang dikenal dengan istilah KTSP, bagi guru dan pelaksana di lapangan sampai saat ini masih merupakan masa peralihan yaitu mencari-cari pola pelaksanaan penilaian yang menurut mereka dianggap terbaik. Karena kondisi seperti ini belum terlambat bagi instansi terkait untuk memberikan arahan secara periodik, khususnya yang berkaitan dengan proses penilaian. Hal ini perlu karena berdasarkan informasi yang diperoleh, para pelaksana di lapangan sangat memerlukan bantuan tersebut.

Dalam rangka membantu mereka di lapangan, ada strategi agar kegiatan menjadi efektif, efisien dan cepat sampai kepada sasaran di pelosok sekali pun. Pertama, instansi pusat menyelenggarakan penataran bagi peserta yang berasal dari tingkat provinsi. Kemudian peserta menjadi penatar bagi peserta yang berasal dari kabupaten/kota yang ada di provinsi mereka masingmasing. Kemudian peserta dari kabupaten dan kota menatar peserta yang berasal dari kecamatan di wilayah mereka masing-masing.
Dengan pertimbangan letak geografis, strategi tersebut dianggap lebih efektif dan efisien dan akan lebih cepat informasi ke daerah terpencil pun. Yang menjadi masalah adalah perlunya ada kesepahaman tentang pentingnya pelaksanaan penataran antara pusat dan daerah sehingga benar-benar berjalan tanpa ada rintangan yang berarti. Di samping itu, perlu dijaga konsistensi kualitas informasi sehingga ketika sampai ke kotakota kecil tidak ada distorsi pemahaman pelaksana di daerah terlepas di kecamatan mana mereka berada.

\section{Simpulan dan Saran}

\section{Simpulan}

Berkaitan dengan diberlakukan Standar Isi (SI), model penilaian Bahasa Indonesia dalam pelaksanaan kurikulum SD merupakan salah satu komponen yang tidak dapat terpisahkan dalam satu kesatuan pembelajaran. Model penilaian ini berbeda dari yang berlaku sebelumnya, lebih kompleks terutama dalam proses penilaiannya dengan menggunakan multi teknik. Karena perbedaan tersebut, maka terjadi perbedaan persepsi dan bahkan perbedaan penggunaan model penilaian di tingkat pelaksana di sebagian SD di Kabupaten/Kota yang berbeda. Ada sebagian SD yang masih menggunakan model penilaian Bahasa Indonesia yang sederhana seperti sebelum diberlakukan SI 2006 yaitu satu angka untuk mata pelajaran Bahasa Indonesia. Tetapi ada SD yang menggunakan model yang lebih kompleks yang menggambarkan pencapaian peserta didik terhadap empat kategori kompetensi berbahasa Indonesia; mendengarkan, berbicara, membaca dan menulis. Adanya perbedaan penggunaan model penilaian Bahasa Indonesia di SD juga diakibatkan oleh adanya kewenangan daerah dalam menentukan model penilaian Bahasa Indonesia di SD.

Penggunaan berbagai model penilaian ini diasumsikan menimbulkan permasalahan bagi peserta didik di SD yang menggunakan model yang sederhana. Dikatakan demikian karena model penilaian memiliki pengaruh kuat terhadap perbelajaran di kelas. Sehingga apabila suatu SD menggunakan model yang sederhana dikhawatirkan proses pembelajarannya tidak mengarah kepada pencapaian peserta didik 
terhadap empat kategori kompetensi Bahasa Indonesia; mendengarkan, berbicara, membaca dan menulis. Akibatnya mereka tidak mencapai keempat kategori kompetensi yang telah ditentukan sebelumnya yang tertuang di dalam SI dan di dalam kurikulum tingkat satuan pendidikan, tepatnya di dalam silabus dan RPP. Karena itu model penilaian Bahasa Indonesia yang ideal dalam pelaksanaan kurikulum SD yang berlaku sekarang adalah model penilaian yang kompeks yang menggambarkan pencapaian peserta didik terhadap keempat kategori keterampilan berbahasa Indonesia tersebut.

\section{Saran}

Meskipun rancangan model penilaian bahasa Indonesia dalam pelaksanaan kurikulum SD diserahkan ke sekolah atau instansi terlait lainnya di daerah, namun instansi pusat yang memiliki gagasan awal adanya perubahan kurikulum perlu mengadakan pembinaan yang merata, dan berkesinambungan. Hal ini penting guna memotivasi pihak sekolah atau unsur terkait di daerah agar model penilaian bahasa Indonesia yang digunakan mencerminkan berbagai aspek/ kategori kompetensi yang dicapai peserta didik sehingga sesuai dengan tuntutan di dalam SI atau kurikulum tingkat satuan pendidikan tepatnya di dalam silabus dan RPP. Pembinaan tentunya memerlukan dana yang tidak sedikit, tetapi bagi pelaksana di lapangan dianggap penting agar mereka dapat melaksanakannya sesuai dengan harapan pemerintah.

Untuk itu, perlu ada perencanaan yang matang tentang strategi pelaksanaan pembinaan agar dapat menekan biaya yang diperlukan seefisien mungkin, namun menjadi efektif. Upaya ini juga diharapkan akan membuka wawasan secara maksimal bagi para pelaksana di lapangan sehingga mereka memahami secara baik pelaksanaan penilaian Bahasa Indonesia yang diharapkan tersebut. Kedepan perlu ada kebijakan yang tegas yang berlaku secara nasional untuk penyeragaman model penilaian Bahasa Indone-

Tabel 2. Rangkuman tiga model penilaian di atas dapat pula dibaca pada matrik merikut

\begin{tabular}{|c|c|c|c|c|}
\hline No. & $\begin{array}{l}\text { Model } \\
\text { Penilaian }\end{array}$ & Aspek yang dinilai & $\begin{array}{ll}\text { Kesesuaian dengan } \\
\text { SPN }\end{array}$ & Catatan \\
\hline 1. & Model 1 & $\begin{array}{l}\text { Yang dinilai dapat ter- } \\
\text { jadi hanya satu, atau } \\
\text { dua, atau tiga, atau } \\
\text { empat kategori kom- } \\
\text { petensi berbahasa } \\
\text { Indonesia. Bahkan da- } \\
\text { pat juga terjadi hanya } \\
\text { konsep atau komponen } \\
\text { bahasa saja. }\end{array}$ & $\begin{array}{l}\text { Sesuai, } \\
\text { khusus-nya di dalam } \\
\text { standar penilaian } \\
\text { dikatakan bahwa di } \\
\text { rapor ditulis satu } \\
\text { angka untuk satu mata } \\
\text { pelajaran. }\end{array}$ & $\begin{array}{l}\text { Tidak jelas kompe- } \\
\text { tensi berbahasa } \\
\text { Indonesia yang di- } \\
\text { capai peserta didik. }\end{array}$ \\
\hline 2. & Model 2 & $\begin{array}{l}\text { Sama dengan model } 1 \text {, } \\
\text { namun ada gambaran } \\
\text { target nilai minimal } \\
\text { yang harus dicapai } \\
\text { peserta didik }\end{array}$ & $\begin{array}{l}\text { Sesuai, sama dengan } \\
\text { model } 1 \text {, hanya saja di } \\
\text { model ini tergambar } \\
\text { target nilai minimal } \\
\text { yang harus dicapai } \\
\text { peserta didik. }\end{array}$ & $\begin{array}{l}\text { Sama dengan model } \\
1 \text {, tidak jelas, namun } \\
\text { digambarkan target } \\
\text { pencapaian minimal. }\end{array}$ \\
\hline 3. & Model 3 & $\begin{array}{l}\text { Yang dinilai pasti } \\
\text { empat keterampilan } \\
\text { berbahasa Indonesia } \\
\text { yang secara implisit } \\
\text { termasuk konsep atau } \\
\text { komponen bahasa. } \\
\text { Dan ini menggambar- } \\
\text { kan pencapaian kom- } \\
\text { petensi peserta didik } \\
\text { "yang sempurna" se- } \\
\text { suai yang ada di SI. }\end{array}$ & $\begin{array}{l}\text { Sesuai dengan SPN } \\
\text { karena khususnya di } \\
\text { dalam standar penilai- } \\
\text { an dikatakan bahwa } \\
\text { proses penilaian meng- } \\
\text { gunakan multi teknik } \\
\text { yang disesuaikan de- } \\
\text { ngan kompetensi yang } \\
\text { dinilai. }\end{array}$ & $\begin{array}{l}\text { Menggambarkan } \\
\text { pencapaian empat } \\
\text { kategori kompetensi } \\
\text { berbahasa sesuai } \\
\text { dengan di SK dan KD } \\
\text { yang ada di SI serta } \\
\text { menggambarkan } \\
\text { penggunaan multi } \\
\text { teknik dalam proses } \\
\text { penilaian seperti } \\
\text { dianjurkan di dalam } \\
\text { SPN. }\end{array}$ \\
\hline
\end{tabular}


sia bagi peserta didik dalam rangka pelaksanaan kurikulum SD yang menggambarkan pencapaian kompetensi berbahasa Indonesia secara utuh yang meliputi empat kategori kompetensi; mendengarkan, berbicara, membaca dan menulis.

Kebijakan ini penting agar pembaca laporan (peserta didik, orang tua, dan orang lain yang berkepentingan) mengetahui secara jelas kompetensi yang telah dicapai peserta didik. Dengan kebijakan ini, sejak masih dalam proses penilaian, guru dengan mudah dapat mengetahui kelemahan dan kelebihan setiap peserta didik terhadap setiap kategori kompetensi berbahasa. Karena itu, guru dapat menentukan dengan mudah siapa yang harus mengikuti remedial untuk kategori kompetensi yang mana.

\section{Pustaka Acuan}

Ambari Sutardi, 1992. Laporan Penelitian Pelaksanaan Cara Belajar Siswa Aktif (CBSA) di Kabupaten Cianjur, Jawa Barat yang diselenggarakan oleh Badan Penelitian dan Pengembangan Pendidikan bekerjasama dengan International Development Research Centre (IDRC) di Otawa, Canada.

Damajanti Kusuma Dewi, 2009. Instructional Theory Course. Definisi Pembelajaran. http:// instructionaltheorycourse.blogspot.com/2009/02/1_introduction_18.html 4 September 2009 (22 Desember 2009).

Departemen Pendidikan Nasional. 2003. Undang-undang Nomor 20, Tahun 2003, tentang Sistem Pendidikan Nasional, Jakarta.

2006. Standar Isi, Standar Kompetensi dan Kompetensi Dasar, Mata Pelajaran Bahasa Indonesia, Jakarta

Google, 2003. Define: Lesson Plan. http://www.dynamicflight.com/avcfibook/glossary/ Last Updated on: 15 November 2003 (27 Desember 2009)

Peraturan Pemerintah Nomor 19, Tahun 2005 tentang Standar Nasional Pendidikan. Jakarta

Peraturan Menteri Pendidikan Nasional-Permendiknas. 2006. Nomor 22, Tahun 2006 tentang Standar Isi untuk satuan pendidikan dasar dan menengah, Jakarta

,2006. Nomor 23 Tahun 2006 tentang Standar Kompetensi Lulusan untuk Satuan Pendidikan Dasar dan Menengah, Jakarta.

2006. Nomor 24 Tahun 2006 tentang Pelaksanaan Peraturan Menteri Pendidikan Nasional Nomor 22 Tahun 2006 tentang Standar Isi untuk Satuan Pendidikan Dasar dan Menengah dan Peraturan Menteri Pendidikan Nasional Nomor 23 Tahun 2006 tentang Standar Kompetensi Lulusan untuk Satuan Pendidikan Dasar dan Menengah, Jakarta.

2007. Nomor 20 tentang Standar Penilaian Pendidikan, Jakarta

2007. Nomor 41 tentang Standar Proses untuk satuan Pendidikan Dasar dan Menengah, Jakarta

Rachel Bolstad. 2004. School-Based Curriculum Development: Principles, Process, and Practices. http:/ Lwww.nzcer.org.nz/default.php?products id=829 (27 Desember 2009)

WIKIPEDIA,2009a. The Free Encyclopedia. Competence (human resources). W http:/en. wikipedia. org/ wiki/Competence_(human_resources). This was last modified on 27 November 2009. (28 Desember 2009)

, 2009b. The Free Encyclopedia. Lesson Plan. W http://en.wikipedia.org/ wiki/Lesson plan. This was last modified on 20 December 2009. (28 Desember 2009.

Yahya Nursidik. 2009. Deskripsi Rancangan Silabus atau Deskripsi Silabus. http:// apadefinisinya. blogspot.com 7 Januari 2009 (16 Desember 2009). 